\title{
Autoimmunity-Related Granulomatous Dermatitis in Association with Hepatitis
}

\author{
Grégory Szepetiuk $^{\mathrm{a}}$ Marianne Lesuisse $^{\mathrm{a}}$ \\ Gérald E. Piérard $^{\mathrm{b}}$ Pascale Quatresooz $^{\mathrm{b}}$ \\ Claudine Piérard-Franchimont ${ }^{\mathrm{b}}$ \\ ${ }^{a}$ Department of Dermatology, Regional Hospital Citadelle, and ${ }^{b}$ Department of \\ Dermatopathology, University Hospital of Liège, Liège, Belgium
}

\section{Key Words}

Granulomatous dermatitis · Autoimmunity - Hepatitis

\begin{abstract}
Aim: Both interstitial granulomatous dermatitis (IGD) and palisaded neutrophilic granulomatous dermatitis (PNGD) are rare disorders typically associated with systemic autoimmune conditions. They probably represent different aspects of a disease spectrum encompassing the concept of autoimmunity-related granulomatous dermatitis (ARGD). Case Report: A 61-year-old woman presented with ARGD and autoimmune hepatitis. The clinical presentation suggested PNGD, while histopathology was consistent with IGD.

Discussion: The association of ARGD with autoimmune hepatitis is apparently a rare event. The present case shows that the clinicopathological correlation in ARGD does not always clearly fit with the classical presentations of IGD or PNGD.
\end{abstract}

\section{Introduction}

A number of autoimmune conditions are associated with cutaneous symptoms. Interstitial granulomatous dermatitis (IGD) is one of these skin disorders [1-3]. The typical clinical presentation corresponds to a linear rope present on the trunk and axillae. On histopathological examination, IGD is characterized by a sparse palisaded histiocytic infiltrate with little neutrophilic debris and eosinophils associated with a necrobiotic aspect of the collagen matrix [4].

In the literature, there is some overlap between IGD and palisaded neutrophilic granulomatous dermatitis (PNGD). Lesions of PNGD typically correspond to papules occasionally admixed with small crusts on the elbows. A dense neutrophilic and 
interstitial histiocytic infiltrate is sometimes associated with vasculitis. Other related disorders include rheumatoid papules, Churg-Strauss granuloma, superficial ulcerating rheumatoid necrobiosis, necrobiotic granuloma, palisading granuloma, cutaneous extravascular necrotizing granuloma, and rheumatoid neutrophilic dermatitis [5].

Here, we report a patient who presented with granulomatous dermatitis in combination with autoimmune hepatitis. Such an association has apparently been reported only once before [6].

\section{Case Report}

A 61-year-old woman presented with skin lesions over the elbows and the left thenar region. They corresponded to erythematous and discrete hyperkeratotic papules which had been present for a few weeks (fig. 1a, b). There was no pruritus.

A skin biopsy was performed. Despite the clinical aspect, the histopathological presentation was consistent with IGD. The dermis contained a moderate superficial perivascular cell infiltrate exhibiting some interstitial extension. A few multinuclear giant cells were recognized. Discrete deposits of acid polysaccharides were identified by colloidal iron stain. Immunohistochemistry revealed the presence of $\mathrm{CD} 3+\mathrm{T}$ lymphocytes predominating in the perivascular area (fig. $2 \mathrm{a}$ ). They were associated with CD68+ and MAC387+ histiocytes as well as factor XIIIa+ dermal dendrocytes (DD1). The patterns of histiocyte distribution were quite distinct regarding cell differentiation. The MAC387+ cells were rather clustered in the vicinity of vessels (fig. 2b), where they were intermingled with lymphocytes. By contrast, CD68+ cells were interspersed between collagen bundles (fig. 2c). The pattern of DD1 distribution was similar to that of CD68+ histiocytes (fig. 2d).

The past medical history of the patient revealed an uneventful cholecystectomy. She presently suffered from allergic asthma. A discretely developing autoimmune hepatitis had been diagnosed 9 years ago. It was characterized by the elevation of anti-smooth muscle antibodies (1:160) and antinuclear antibodies $(1: 1,280)$. There were no detectable antibodies directed against nuclear antigens, keyhole limpet hemocyanin and mitochondria. Hepatitis B and C serologies were negative.

At the time of presentation, the patient's liver tests were in the normal range. She had never received any treatment to control the autoimmune hepatitis. She received a topical corticosteroid treatment that temporarily improved the skin lesions. However, they recurred a few months later, and some other lesions appeared on the thighs.

\section{Discussion}

In some cases, there is a mismatch between the clinical presentation and the histopathological patterns of IGD and PNGD [7]. Indeed, these two conditions possibly represent a continuum or progression of a single disease process corresponding to autoimmunity-related granulomatous dermatitis (ARGD) [6, 8]. The clinical associations between ARGD, autoimmune disease and lymphoproliferative disorders have been intermixed between both IGD and PNGD diagnoses in the literature [6, 914]. The underlying disorder is sometimes not diagnosed at the time of the skin manifestations [15]. IGD and PNGD are probably related disorders in the spectrum of ARGD. It is acknowledged that the inflammatory cell infiltrate is sparse to moderate in IGD, while PNGD has a dense neutrophilic and interstitial histiocytic infiltrate [5]. Some unusual variants have been reported [16].

To the best of our knowledge, only a single case of IGD with autoimmune hepatitis [17] association has been reported so far [6]. Some other autoimmune comorbidities 
including arthritis, antiphospholipid syndrome $[18,19]$ and hematologic malignancy [20] have been reported in association with IGD. In addition, interstitial granulomatous drug reactions have been linked to TNF inhibitors, ACE inhibitors, diuretics [21-28] and soy products in food [29]. This eventuality was ruled out in our patient.

\section{Disclosure Statement}

The authors have no conflicts of interest to declare.
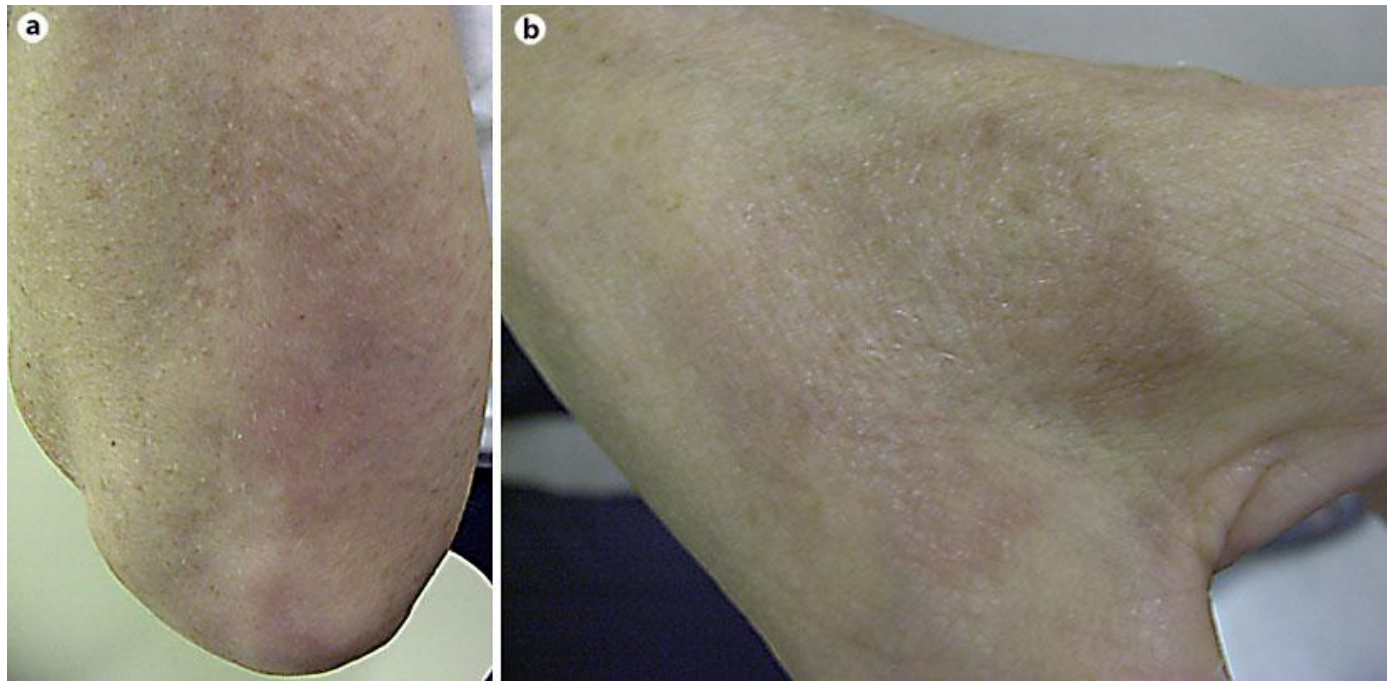

Fig. 1. Clinical presentation of ARGD. a Multiple papules in a plaque on the elbow. b Multiple papules grouped on the thenar region. 

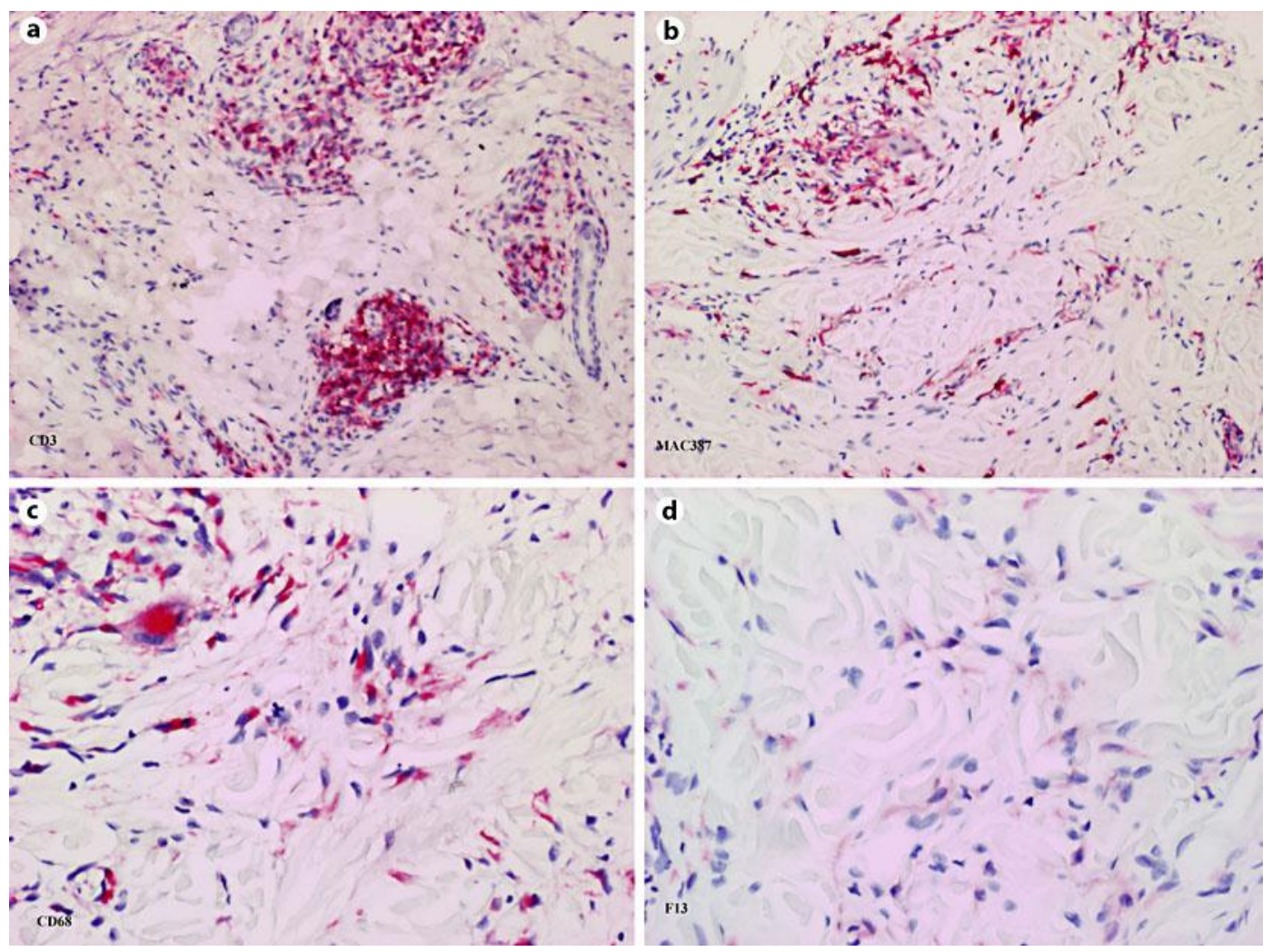

Fig. 2. Immunohistopathology of an ARGD papule. a Perivascular clusters of CD3+ lymphocytes $(\times 200)$. b Perivascular distribution of MAC387+ macrophages $(\times 200)$. c Interstitial spread of CD68+ macrophages $(\times 200)$. $\mathbf{d}$ Interstitial presence of factor XIIIa+ DD1 $(\times 200)$.

\section{References}

$\checkmark 1$ Tomasini C, Pippione M: Interstitial granulomatous dermatitis with plaques. J Am Acad Dermatol 2002;46:892-899.

-2 Lee HW, Chang SE, Lee MW, Choi JH, Moon KC, Koh JK: Interstitial granulomatous dermatitis with plaques associated with antiphospholipid syndrome. Br J Dermatol 2005;152:814-816.

-3 Felcht M, Faulhaber J, Göttmann U, Koenen W, Goerdt S, Goebeler M: Interstitial granulomatous dermatitis (Ackerman's syndrome). Eur J Dermatol 2010;20:661-662.

4 Peroni A, Colato C, Schena D, Gisondi P, Girolomoni G: Interstitial granulomatous dermatitis: a distinct entity with characteristic histological and clinical pattern. Br J Dermatol 2011; Epub ahead of print.

-5 Hawryluk EB, Izikson L, English JC 3rd: Non-infectious granulomatous diseases of the skin and their associated systemic diseases: an evidence-based update to important clinical questions. Am J Clin Dermatol 2010;11:171-181.

6 Lee KJ, Lee ES, Lee DY, Jang KT: Interstitial granulomatous dermatitis associated with autoimmune hepatitis. J Eur Acad Dermatol Venereol 2007;21:684-685.

$\checkmark 7$ Aloi F, Tomasini C, Pippione M: Interstitial granulomatous dermatitis with plaques. Am J Dermatopathol 1999;21:320-323.

8 Chu P, Connolly MK, LeBoit PE: The histopathologic spectrum of palisaded neutrophilic and granulomatous dermatitis in patients with collagen vascular disease. Arch Dermatol 1994;130:12781283. 
9 Bremner R, Simpson E, White CR, Morrison L, Deodhar A: Palisaded neutrophilic and granulomatous dermatitis: an unusual cutaneous manifestation of immune-mediated disorders. Semin Arthr Rheum 2004;34:610-616.

10 Germanas JP, Mehrabi D, Carder KR: Palisaded neutrophilic granulomatous dermatitis in a 12-year-old girl with systemic lupus erythematosus. J Am Acad Dermatol 2006;55:S60-S62.

11 Asahina A, Fujita H, Fukunaga Y, Kenmochi Y, Ikenaka T, Mitomi M: Early lesion of palisaded neutrophilic granulomatous dermatitis in ulcerative colitis. Eur J Dermatol 2007;17:234-237.

12 Biswas A, Chittari K, Gey van Pittius D, Stephens M, Tan BB: Palisaded neutrophilic and granulomatous dermatitis in a child with type I diabetes mellitus and celiac disease. Br J Dermatol 2008;159:488-489.

13 Hantash BM, Chiang D, Kohler S, Florentino D: Palisaded neutrophilic and granulomatous dermatitis associated with limited systemic sclerosis. J Am Acad Dermatol 2008;58:661-664.

14 Garcia-Rabasco A, Esteve-Martinez A, Zaragoza-Ninet V, Sanchez-Carazo JL, Alegre-de-Miquel V: Interstitial granulomatous dermatitis in a patient with lupus erythematosus. Am J Dermatopathol 2011;33:871-872.

15 Misago N, Shinoda Y, Tago M, Narisawa Y: Palisaded neutrophilic granulomatous dermatitis with leucocytoclastic vasculitis in a patient without any underlying systemic disease detected to date. J Cutan Pathol 2010;37:1092-1097.

16 Patsatsi A, Kyriakou A, Triantafyllidou E, Sotiriadis D: Interstitial granulomatous dermatitis: another clinical variant. Case Rep Dermatol 2011;3:195-200.

17 Albert JC: Autoimmune hepatitis; in Feldman M, Tschumy WO, Friedman LS, et al. (eds): Sleisenger and Fordtran's Gastrointestinal and Liver Disease, ed 7. Philadelpia, Saunders, 2002, pp 1471-1472.

18 Verneuil L, Dompmartin A, Comoz F, Pasquier CJ, Leroy D: Interstitial granulomatous dermatitis with cutaneous cords and arthritis: a disorder associated with autoantibodies. J Acad Dermatol 2001;45:286291.

19 Busquets-Perez N, Narvaez J, Valverde-Garcia J: Interstitial granulomatous dermatitis with arthritis (Ackerman syndrome). J Rheumatol 2006;33:1207-1209.

20 Swing DC Jr, Sheehan DJ, Sangueza OP, Woodruff RW: Interstitial granulomatous dermatitis secondary to acute promyelocytic leukemia. Am J Dermatopathol 2008;30:197-199.

21 Magro CM, Crowson AN, Schapiro BL: The interstitial granulomatous drug reaction: a distinctive clinical and pathological entity. J Cutan Pathol 1998;25:72-78.

22 Perrin C, Lacour JP, Michiels JF: Interstitial granulomatous drug reaction with a histological pattern of interstitial granulomatous dermatitis. Am J Dermatopathol 2001;23:295-298.

23 Fujita Y, Shimizu T, Shimizu H: A case of interstitial granulomatous drug reaction due to sennoside. Br J Dermatol 2004;150:1035-1037.

24 Lee HW, Yun WJ, Lee MW, Choi JH, Moon KC, Koh JK: Interstitial granulomatous drug reaction caused by Chinese herbal medication. J Am Acad Dermatol 2005;52:712-713.

25 Deng A, Harvey V, Sina B, Strobel D, Badros A, Junkins-Hopkins JM, Samuels A, Oghilikhan M, Gaspari A Interstitial granulomatous dermatitis associated with the use of tumor necrosis factor alpha inhibitors. Arch Dermatol 2006;142:198-202.

26 Chen YC, Hsiao CH, Tsai TF: Interstitial granulomatous drug reaction presenting as erythroderma: remission after discontinuation of enalapril maleate. Br J Dermatol 2008;158:1143-1145.

27 Groves C, McMenamin ME, Casey M, Bames L: Interstitial granulomatous reaction to strontium ranelate. Arch Dermatol 2008;144:268-269.

28 Marcollo Pini A, Kerl K, Kamarachev J, French LE, Hofbauer GF: Interstitial granulomatous drug reaction following intravenous ganciclovir. Br J Dermatol 2008;158:1391-1393.

29 Dyson SW, Hirsch A, Jaworsky C: Interstitial granulomatous dermatitis secondary to soy. J Am Acad Dermatol 2004;51:S105-S107. 